\title{
BALANCED SCORECARD IN MANUFACTURING COMPANY
}

\author{
Meutia Rahma \\ Sigit Handoyo \\ sihando@yahoo.com \\ Univeristas Islam Indonesia
}

\begin{abstract}
Due to the competitiveness in business world has been rising rapidly; the company must be able to enhance its performance in order to compete with other competitors. In measuring the performance, company should have a good performance measurement system that can assess the company's performance comprehensively and appropriately. Balanced scorecard assessed to become a comprehensive and appropriate performance measurement systems that help the organization not only measure the performance but also manage the strategies. In this research, the researchers aim to analyze the current performance measurement systems applied in PT. Yokatta Indonesia as a sample. The type of research method is qualitative research and uses descriptive qualitative. Questionnaire has been tested for validity and reliability by using SPSS for Windows Release 19.0. Data analysis is used triangulation in combining several qualitative and quantitative data. From the results, performance measurement system balanced scorecard is being implemented in PT. Yokatta Indonesia not appropriately with considering some factors related with management style, additional costs, and also company infrastructures.
\end{abstract}

Keywords: performance measurement, balanced scorecard, strategic planning

\section{RESEARCH BACKGROUND}

Nowadays, the competitive in business world has been rising rapidly. Business company which are categorized in industry, trade and service sectors must enhance their performance in order to be able compete with other companies. Due to the changing of industrial era into information era, business competitiveness environment is getting tighter. Seeing this condition, many competitors quickly enter the industries and determine to choose the best strategy. Only excellent companies can satisfy and fulfill customer needs to be able to provide quality products and effective cost. Therefore, having good strategic management systems is important factor that must be concerned to reach high probability of successful organizations.

Based on Mulyadi (2001), strategic management systems includes two stages (1) planning and (2) implementation. Planning stage is divided into four stages namely (1) strategy formulation, (2) strategic planning, (3) programming, and (4) budgeting. Besides, implementation stage is divided into two stages (1) implementation and (2) monitoring. The role of strategic planning in determining the strategic objective has become crucial after translating 
vision and mission to all members of organization because it is related with the company goals.

In order to achieve similar vision and mission, a company should make innovative strategic management system to face the complex and turbulent business and enhance their performance in order to achieve success organizations. As mentioned by Sinha (2006), the most important thing that can ensure the success of any organization is the development of appropriate strategies which would decide the direction the organization will take as it progresses. In order to know how good or bad the company performance, a tool such as performance measurement to make an evaluation is needed. Balanced scorecard measurement can be the option for the company to measure their performance. This measurement indicates the achievement of strategic objectives because it measures both outcome measures and performance drivers. Adhyaksa (2002) stated that outcome measures are lagging indicators which reporting how well the company's strategy implemented in the past and performance drivers are leading indicators that significantly influence the lagging indicators in the future.

Using balanced scorecard did not have to rely on short-term as the sole indicators of the company's performance. The scorecard allows to them introduce four new management processes that, separately and in combination, contribute to linking long-term strategic objectives with shortterm actions. Therefore, management can be easier to measure a company performance through four perspectives and predict the company future performance. Long-term performances are more important compare to short-term performances, It because the company should be able to struggle in the new environment of global competitiveness.

Sinha(2006) stated that balanced scorecard is a very important strategic management tool which helps the organization not only measure the performance but also manage the strategies which are needed to be adopted so that the long terms goals are achieved. While Kumari (2011) stated that in implementing balanced scorecard, organizations are striving to become a strategy focused organizations. Then, the conclusion is that balanced scorecard focused on the strategic management in translating the vision and mission into several objectives to achieve long-term goals.

\section{Research Questions}

Based on the background study above, the primary research questions of this study is as follows:

"How PT Yokatta Indonesia implement balanced scorecard as performance measurement?"

\section{LITERATURE REVIEW}

\section{Definition of Balanced Scorecard}

According to Mulyadi (2001), scorecard means used to compared the future score with the real performance and the result is used to evaluate the personal performance. Meanwhile, balanced shows the personal performance was measured by two aspects. Those aspects include financial and non-financial, short-term and long-term, and also intern and extern performances.

According to Kaplan and Norton (1996) the balanced scorecard is based on four key perspectives. The first is the financial goals, which is "How will we look to our stake holders?". The second is customer perspective, which is "How must we look to our customers?". The third is internal processes, which is "What internal processes must we excel at?". The last is learning and growth, which is "How can the organization learn and improve?" In the explanation above, we can conclude that balanced scorecard is a strategic management tool in measuring the company performance not only in financial but also non-financial aspects. 


\section{Balanced Scorecard Perspective}

Balanced scorecard has 4 perspectives to be measured, they are Financial Perspective, Customer Perspective, Internal Business Process Perspective and Learning and Growth Perspective

\section{Financial Perspective}

Adhyaksa (2002) stated that financial measure in balanced scorecard is still applied because it summarizes the economic consequences and it shows the success of strategic planning and implementation. Balanced scorecard using financial performance benchmarks such as Net Income (NI) and Return on Investment (ROI), because the benchmarks are commonly used within the company to determine the profit. Unfortunately, financial benchmarks alone cannot describe the triggers that make changes in the wealth created by the company or organization (Mulyadi and Setyawan, 2000).

\section{Customer Perspective}

This perspective measures the effort of the company to satisfy the customer. In measuring this perspective, the measuring rods are divided into two groups. The first group is core measurement. In the core measurement group it is measuring customer satisfaction, customer acquisition, customer loyalty, customer profitability and the market share. According to Kaplan and Norton (1996) the core measurements of customer perspective are Market share, Customer retention, Customer acquisition, Customer satisfaction and Customer profitability

\section{Internal Business Process Perspective}

Internal business process perspective displays critical processes that enable the business unit to provide. Each company has a set of unique value creation process for its customers. In general, Kaplan and Norton (1996) to divide them into three basic principles, namely: process innovation, process operations, and after sales service

\section{Learning and Growth Perspective}

In this perspective, there are three important dimensions that must be consider for the assessment of performance is the people, systems, and organizational procedures (Kaplan and Norton, 2001), namely: 1) people such as, Employee satisfaction, Employee retention and Employee productivity, 2) System which is system information needed by employees and, 3) Organizational procedure performed an organization need to be considered to achieve a reliable performance.

\section{RESEARCH METHOD}

\section{Type of Research Method}

Type of research method which used by the researcher is qualitative research focused on case study.

\section{Research Object}

Research object which is used in this research is PT. Yokatta Indonesia, automotive and non-automotive rubber manufacturing company in Cikarang, Jakarta.

\section{Population and Sample}

Based on information gathering from PT. Yokatta Indonesia, the total population of employee is 63 people and customer is 20 companies. Sample for interview are using purposive sampling while for customer are using simple random sampling. This sample consists of director, financial managers, personnel managers/ human resources development, warehouse manager, and sales manager. Sample of employee are 54 and for customer are 19. The sampling measurement is determined by using the Slovin Formulation as follows: 


$$
n=\frac{N}{1+N e^{2}}
$$

Where:

h : Sample Size

N : Population Size

e : Error Tolerance (the researcher use 5\%)

\section{Type and Sources of Data}

This research is using primary and secondary data. Primary data in this research are History, vision, mission and the company development, Organizational structure and job description, Company strategic planning, and Customer and employee satisfaction

Meanwhile, secondary data in this research are used to analyze perspectives in balanced scorecard. To analyze financial perspective, the secondary data are revenue of 2011 and 2012 and balance sheet for 2011 and 2012. To analyze customer perspective, the secondary data are customer acquisition and customer retention. To analyze internal business process, the secondary data are new product sales, balance sheet of 2011 and 2012, and Manufacturing Cycle Effectiveness (MCE). To analyze learning and growth perspective, the secondary data are employee retention and employee's productivity.

\section{Data Collection Method}

Data collected is obtained by applying: Interview (In-depth interview), Observation (Passive Observation), Questionnaire, Documentation, and Study Literature.

\section{Data Analysis Method}

Data analysis method that used in this research is data reduction, data display, and conclusion drawing or verification. It can be illustrated as shown below.

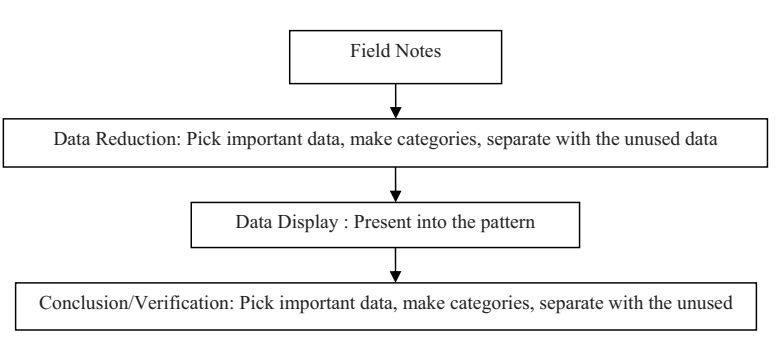

Figure 1. Data Analysis Steps
Sumber: Sugiyono, 2013: 94

In this research, it is used also descriptive qualitative research. In combining several qualitative and quantitative researches, the researcher used triangulation. In combining several qualitative and quantitative researches such as interviews, the methodological perspectives complement each other in the study of an issue and this is conceived as the complementary compensation of the weaknesses and blind spots of each single method (Flick, 2002). The answers to the questionnaires are analyzed for their frequency and distribution across the whole sample and the answers in the interviews are analyzed and compared, and for example a typology is developed. Then the distribution of the questionnaire answers and the typology are linked and compared. The model of triangulation in qualitative and quantitative can be shown in Figure 3.2.

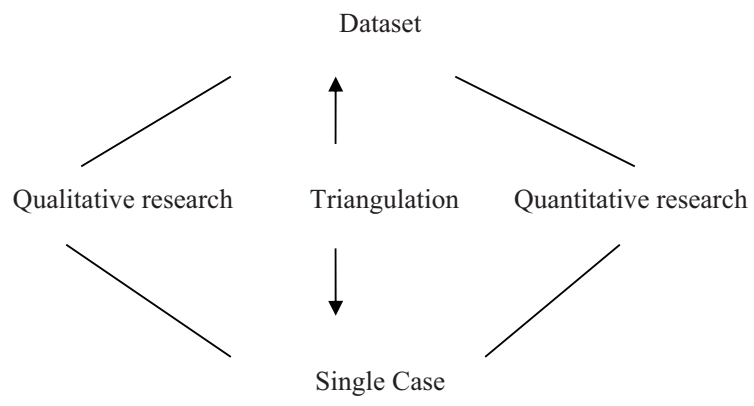

Single Case

Figure 2. Triangulation of Qualitative and Quantitative Research Source: Flick (2002) 
Meanwhile, to calculate the customer's questionnaire it is used Likert Scale. Ghozali (2005) stated that likert scale contain of five degree response with alternatives as scale number $1-5$, which is means as very unsatisfied has score number 1 , unsatisfied has score number 2 , enough satisfied has score number 3, satisfied has score number 2, and very satisfied has score number 5 .

\section{Key Instruments}

The key instruments in this research are the researcher as validation of the readiness to conduct further research fieldwork. This validation includes the understanding of qualitative research methods, deeper understanding of theory and readiness to enter the field.

\section{Data Quality Testing}

Data Quality testing which researcher will be used in this research is extension of participation as many as 5 times and triangulation of sources, techniques, and time. For questionnaire, the data quality testing are validity test and reliability test. Validity test is in the questionnaire by observing Correlation Coefficient Number (Rxy) and validity measured by comparing the value of $r$ count (item total correlation) with the value of $r$ table. For reliability test, it uses alpha coefficient from Cronbach. Both of validity and reliability test are using SPSS software program version 19.00 .

\section{DATA ANALYSIS}

\section{Current Performance Measurement Systems in PT. Yokatta Indonesia}

PerformanceMeasurementsystemareused after the company had done the implementation which influenced by the operational activities in utilized available resources. In evaluating the performance, PT. Yokatta Indonesia has focused on the increasing the sales related of revenue growth and squeezing down the production cost.
The measurement systems based on the financial perspective is used in this company as the main measurement because the management is quite easy to measure the performance management through quantitative number. In measuring the performance of the company whether is good or not, they have notice more carefully in sales and production cost compared from previous year. In terms of sales, the company pointed out at Break Even Point (BEP). If the company reach the sales revenue about 1.2 billion rupiahs per month, the company will earn a profit. Therefore, if the sales revenue can meet the Break Even Point targets and higher compared to last year, the performance of the company considered as good. While in measuring the production costs, the company compares it with previous year. If there is a decreasing amount of production costs supporting with sales increase, it shows a good performance. The scoring number given by customer assesses the company's performance in terms of product cost, product quality, and ontime delivery product. Since the customer has many options to choose their supplier, then this company has tried to fulfill the customer needs. For the employee, the important foundation in balanced scorecard perspective, the training program has not been conduct routinely. Due to the limitation of fund in doing those programs, the company is still looking for free training which makes the company's program become less effective.

\section{The Implementation of Balanced Scorecard}

In implementing balanced scorecard, there are several steps need to be done by a researcher such as clarify mission and vision statement, break the vision down according to four perspective and formulate strategic objectives, identify leading indicators and lagging indicators and establish a balance. The process of designing balanced scorecard be explained as follows: 


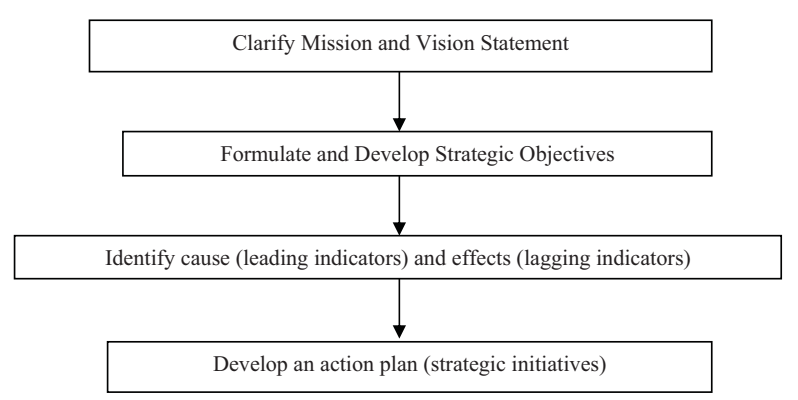

Figure 3. Process of Designing Balanced Scorecard

Source: Kumari, 2011: 83

\section{Clarify Mission and Vision Statement}

- Vision : To be Indonesian Leading Rubber Manufacturing Company.

- Mission : Serve our valuable customers to solve their needs and support with solution and through enhancement in technology and process.

After the vision and mission has been created, further step is interpreting the impact of external changing trend as a trend watching and the internal analysis as a SWOT analysis (Mulyadi, 2001). The using of SWOT analysis is to clarify vision and mission statement based on the company's strategies and goals. There are SWOT analyses on the PT. Yokatta Indonesia, as follows:

\section{Factors that give Strength:}

a. PT. Yokatta Indonesia has high capital from private investment in running the business.

b. The completeness of machine and equipment has supported the operational activities.

c. PT. Yokatta Indonesia has a good integrated rubber plan

\section{Factors that give weaknesses:}

a.Not supported by the good infrastructure, the capacity is not comparable with the facilities and the location is located on the place that not easy to reach. b. There are big turnover employee and small number of skilled employees.

c. PT. Yokatta Indonesia's accounting system is manually operation.

Having analyzed the internal condition, management also analyzed external condition that contributes opportunities and threats to the company, such as:

1. Factors that give opportunities are:

a. PT. Yokatta Indonesia has a big chance to go to wider market as long as the capital to sustain it.

b. Quality of the products are trusted since they have a complete equipment to make raw material and integrated rubber plan.

\section{Factors that give threats are:}

a. The current location that is not easy to reach

b. High turnover employee may cause the operational activities disturbed and affect the profit of the company.

c. There are so many competitors since the competition among middle level manufacturing company is getting tight.

Meanwhile, PT. Yokatta Indonesia has set up some goals interpreting from the vision, as follows:

1. Indonesia leading rubber manufacturing company

2. Sell products in OEM(Original Equipment Manufacturer) in order to achieve strong financial

3. Have competent and qualified employees

4. Provide more value to customers

Based on the goals that set by the company, there are some strategies to achieve the goals. The company formulates the strategies which expected has long-term impact, as follows:

1. Expand the market target of company

2. Improve the operational activities in order to increase quality of product.

3. Maximize the availability of human resources and knowledge workers. 
4. To be learning organization in terms of customer.

\section{Formulate and develop strategic objectives}

There are four strategic objectives that researcher tries to formulate based on theory related balanced scorecard in terms of financial perspective, customer perspective, internal business process perspective, and learning and growth perspective.

The strategic objectives of the company in financial perspectives consist of increase financial return to shareholders, increase revenue of sales and decrease production cost. Adhyaksa (2002) stated that using financial benchmarks such as net income and Return On Investment (ROI) will help the company to easily determine the profit. Kaplan and Norton (1996) also asserted that increase financial return to shareholders because it shows the success of strategic planning and implementation. Considering increase revenue of sales and decrease production has become the performance measurement of the company, it will be the strategic objectives.

The strategic objectives of the company in customer perspectives consist of increase in new customer, increase customer loyalty and increase customer satisfaction. In customer perspective, customer should feel satisfied. Kumari (2011) stated that customers should be analyzed in terms of kind of customers and kind of processes. The company must keep the old customers and increase new customers. Moreover, trust and loyalty in customer should enhance in reflecting their satisfaction. According to Kaplan and Norton (1996), the company should keep the old customers, increase new customers, and make them feel satisfied is become a part of core measurements in financial perspectives.

The strategic objectives of the company in internal business perspectives consist of increase product innovation, increase the effectiveness of Manufacturing Cycle Effectiveness (MCE) and improve post sales service. Increase customer loyalty. In internal business perspectives, Kaplan and Norton (1996) stated that each company should have unique value creation process for its customers which is conclude in terms of process innovation, process operations, and after sales service. After sales services should be improved in order to know the service response time of customer (Mulyadi, 2001).

The strategic objectives of the company in learning and growth perspectives consist of increase employee skills, improvement of employee productivity, and increase employee satisfaction. In learning and growth perspectives, the company should align employees and organizational goals in order to increase employee satisfaction, develop their skills and improving the productivity of employee due to the lack of human resources (Widodo, 2011). While Kumari (2011) stated that people are the main resource in a knowledge worker organization and the only repository of knowledge. According to Kaplan and Norton (2000) stated that there are three things needs to be reviewed in terms of human resources while implementing balanced scorecard such as employee satisfaction, employee retention, and employee productivity.

\section{Identify lag indicator, lead indicator, and strategic initiatives}

Lag indicator of strategic measurements are based on strategic objectives that have been made previously. The analysis results on lag indicator are needed to formulate the lead indicator and strategic initiatives. In determining lag indicator, it is used several formula and indicators to know the assess company's performances.

\section{Financial Perspectives}

In terms of financial perspectives, there are Return On Investment (ROI), Gross Profit Margin, revenue growth and production costs that become the lag indicator of strategic measurements of the company, as follows: 


\section{ROI}

Formula:

$$
\mathrm{ROI}=\underline{\text { Net Profit-Initial investment }} \times 100
$$

Sources: ("How to Calculate ROI", n.d.)

Indicator:

ROI can be said as effective if the level of ROI is higher, it is shows that the more also the ability of the company in managing the operation activities and the profit will become higher also (Widodo, 2011).

Result:

\begin{tabular}{|c|c|c|}
\hline \multicolumn{3}{|c|}{ ROI } \\
\hline 2011 & -0.63 & \multirow{2}{*}{ Effective } \\
\hline 2012 & -27.34 & \\
\hline
\end{tabular}

\section{Gross Profit Margin}

Formula:

$$
\begin{aligned}
\text { Gross Profit Margin }= & \underline{\text { Gross Profit }} \\
& \text { Total Revenue }
\end{aligned}
$$

Sources: Widodo (2011)

Indicator:

Table 4.3. Indicator of Gross Profit Margin

\begin{tabular}{|l|l|}
\hline Well & $>6 \%$ \\
\hline Average & $6 \%$ \\
\hline Bad & $<6 \%$ \\
\hline
\end{tabular}

Sources: Widodo (2011)

\begin{tabular}{|c|c|c|c|}
\hline Revenue & 2011 & 2012 & $\begin{array}{c}\% \text { of increase } \\
\text { (decrease) }\end{array}$ \\
\hline $\begin{array}{c}\text { Sales of } \\
\text { automotive and } \\
\text { non- automative } \\
\text { rubber product }\end{array}$ & Rp 5,378,544,031 & $\begin{array}{l}\text { Rp } \\
17,666,341,980\end{array}$ & $228.40 \%$ \\
\hline
\end{tabular}

Result:

\begin{tabular}{|c|c|c|}
\hline \multicolumn{3}{|c|}{ Gross Profit Margin } \\
\hline 2011 & $-3.09 \%$ & $\mathrm{Bad}$ \\
\hline 2012 & $-37.30 \%$ & $\mathrm{Bad}$ \\
\hline
\end{tabular}

\begin{tabular}{|c|c|c|c|c|}
\hline \multicolumn{2}{|c|}{ Production Cost } & 2011 & 2012 & $\begin{array}{c}\% \text { of increase } \\
\text { (decrease) }\end{array}$ \\
\hline \multicolumn{2}{|c|}{ Cost of Manufacturing } & Rp 7,697,007,707 & $\begin{array}{l}\mathrm{Rp} \\
17,737,299,150\end{array}$ & $130.44 \%$ \\
\hline \multirow{2}{*}{$\begin{array}{l}\text { Strategic } \\
\text { Objectives }\end{array}$} & \multicolumn{3}{|c|}{ Strategic Measurements } & \multirow{2}{*}{ Strategic Initiatives } \\
\hline & Las & dicator & Lead Indicator & \\
\hline \multirow{2}{*}{$\begin{array}{l}\text { Increase } \\
\text { financial returns }\end{array}$} & $-\mathrm{RC}$ & & & \\
\hline & $-\mathrm{Gr}$ & Profit Margin & & \\
\hline $\begin{array}{l}\text { Increase sales } \\
\text { revenue }\end{array}$ & \multicolumn{2}{|c|}{ - Revenue Growth } & $\begin{array}{l}\text { - Increase } \\
\text { Marketing }\end{array}$ & $\begin{array}{l}\text { - Build strong customer } \\
\text { relationship }\end{array}$ \\
\hline $\begin{array}{l}\text { Decrease } \\
\text { Production } \\
\text { costs }\end{array}$ & \multicolumn{2}{|c|}{ - Maintenance costs } & $\begin{array}{l}\text { - Maintain the } \\
\text { machine }\end{array}$ & $\begin{array}{l}\text { - Checking routinely } \\
\text { in avoiding defect } \\
\text { machine }\end{array}$ \\
\hline
\end{tabular}

\section{Revenue Growth}

\section{Production Costs}

\section{Customer Perspectives}

In terms of customer perspectives, there are customer acquisitions, customer retention, and customer satisfaction that become the lag indicator of strategic measurements of the company, as follows:

\section{Customer Acquisition}

\section{Formula:}

$$
\begin{aligned}
& \text { Customer Acquisition }= \text { New Customer } \times 100 \% \\
& \text { Total Customer }
\end{aligned}
$$

Sources:Adhyaksa (2002)

Indicator:

Table 4.5 Indicator of Customer Acquisition

\begin{tabular}{|l|l|l|}
\hline Acquisition & Decreasing & Bad \\
\hline & Constant & Average \\
\hline & Fluctuated & Average \\
\hline & Increasing & Good \\
\hline
\end{tabular}

Sources: Kaplan (2000) 
$\underline{\text { Result: }}$

\begin{tabular}{|c|c|c|}
\hline \multicolumn{3}{|c|}{ Customer Acquisition } \\
\hline 2011 & $24 \%$ & \multirow{2}{*}{ Good } \\
\hline 2012 & $39 \%$ & \\
\hline
\end{tabular}

\section{Customer Retention}

Formula:

$$
\begin{gathered}
\text { Customer Retention }=\underline{\text { Old Customer }} \times 100 \% \\
\text { Total Customer }
\end{gathered}
$$

Sources: Adhyaksa (2002)

Indicator:

Table 4.6 Indicator of Customer Retention

\begin{tabular}{|l|l|l|}
\hline Measurement & Value & Criteria \\
\hline Retention & Decreasing & Bad \\
\hline & Constant & Average \\
\hline & Fluctuated & Average \\
\hline & Increasing & Good \\
\hline
\end{tabular}

Sources: Kaplan (2000)

Result:

\begin{tabular}{|c|c|c|}
\hline \multicolumn{3}{|c|}{ Customer Retention } \\
\hline 2011 & $73 \%$ & \multirow{2}{*}{ Good } \\
\hline 2012 & $85 \%$ & \\
\hline
\end{tabular}

\section{Customer Satisfactions}

\begin{tabular}{|c|c|c|c|}
\hline \multirow{2}{*}{$\begin{array}{c}\text { Strategic } \\
\text { Objectives }\end{array}$} & \multicolumn{2}{|c|}{ Strategic Measurements } & \multirow{2}{*}{$\begin{array}{l}\text { Strategic } \\
\text { Initiatives }\end{array}$} \\
\hline & Lag Indicator & Lead Indicator & \\
\hline $\begin{array}{l}\text { Increase } \\
\text { customer trust }\end{array}$ & $\begin{array}{l}\text { Customer } \\
\text { Acquisition }\end{array}$ & $\begin{array}{l}\text { Image and } \\
\text { reputation }\end{array}$ & $\begin{array}{l}\text { Identify new } \\
\text { target customer } \\
\text { segment }\end{array}$ \\
\hline $\begin{array}{l}\text { Increase } \\
\text { customer } \\
\text { lovalty }\end{array}$ & $\begin{array}{l}\text { Customer } \\
\text { retention }\end{array}$ & $\begin{array}{l}\text { Depth of } \\
\text { relationship }\end{array}$ & $\begin{array}{l}\text { Create the link } \\
\text { with customers }\end{array}$ \\
\hline $\begin{array}{l}\text { Increase } \\
\text { customer } \\
\text { satisfaction }\end{array}$ & $\begin{array}{l}\text { Customer } \\
\text { Satisfaction }\end{array}$ & $\begin{array}{l}\text { Percentage } \\
\text { number of } \\
\text { customer } \\
\text { satisfied }\end{array}$ & $\begin{array}{l}\text { Increase } \\
\text { customer focus } \\
\text { of sales }\end{array}$ \\
\hline
\end{tabular}

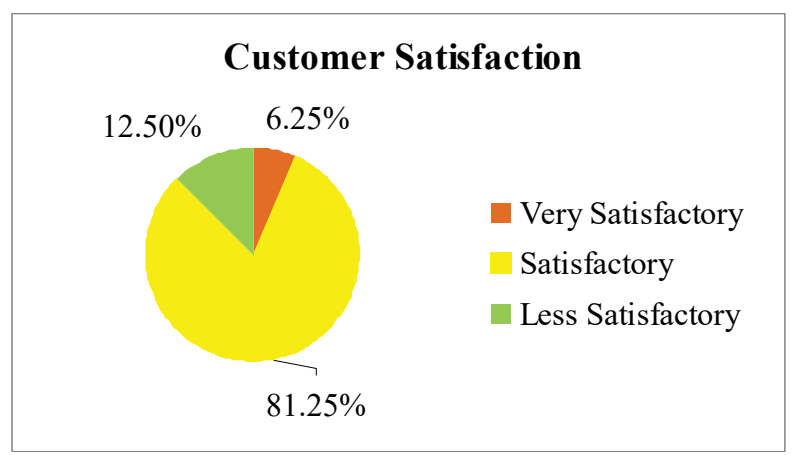

\section{Internal Business Perspectives}

\section{Innovation Product}

Indicator:

Indicators of Innovation Product

\begin{tabular}{|l|l|l|}
\hline Measurement & Value & Criteria \\
\hline Innovation & Decrease & Bad \\
\cline { 2 - 3 } & Constant & Average \\
\cline { 2 - 3 } & Fluctuated & Average \\
\cline { 2 - 3 } & Increase & Good \\
\hline
\end{tabular}

Sources: Kaplan (2000)

Result:

\begin{tabular}{|c|c|c|}
\hline \multicolumn{3}{|c|}{ Innovation Product } \\
\hline Year & Result & \multirow{2}{*}{ Bad } \\
\hline 2011 & $\operatorname{Rp~} 1,083,814,391.57$ & \\
\hline 2012 & $\operatorname{Rp~493,670,518.80}$ & \\
\hline
\end{tabular}

\section{Manufacturing Cycle Effectiveness (MCE)}

Formula:

$$
\begin{aligned}
& \text { Manufacture Cycle Effectiveness }=\frac{\text { Processing Time }}{\text { Throughput Time }} \\
& \begin{array}{l}
\text { Where: } \\
\text { Throughput Time }=\text { Processing Time }+ \text { Inspection Time }+ \text { Movement Tim }
\end{array} \\
& \text { Indicator: } \\
& \text { MCE } \rightarrow 0 \text {, implies inefficient process } \\
& \text { MCE } \rightarrow 1 \text {, implies less wasted time, greater efficiency }
\end{aligned}
$$

Throughput Time $=$ Processing Time + Inspection Time + Movement Time + Waiting Storage Time

Sources: Kaplan and Norton (1996) 
Result:

\begin{tabular}{|c|l|r|l|}
\hline \multicolumn{4}{|c|}{ Manufacturing Cycle Effectiveness (MCE) } \\
\hline Year & \multicolumn{1}{|c|}{ Category } & \multicolumn{2}{|c|}{ Result } \\
\hline 2012 & Non-Metal Rubber (Fast) & $87.2 \%$ & Efficient \\
\hline \multirow{2}{*}{} & Non-Metal Rubber (Medium) & $84.2 \%$ & Efficient \\
\hline & Non-Metal Rubber (Slow) & $81.3 \%$ & Efficient \\
\hline & Metal Rubber (Fast) & $84.2 \%$ & Efficient \\
\hline & Metal Rubber (Medium) & $94 \%$ & Efficient \\
\hline & Metal Rubber (Slow) & $72.7 \%$ & Efficient \\
\hline
\end{tabular}

\begin{tabular}{|c|c|c|c|}
\hline \multirow{2}{*}{$\begin{array}{l}\text { Strategic } \\
\text { Objectives }\end{array}$} & \multicolumn{2}{|c|}{ Strategic Measurements } & \multirow{2}{*}{$\begin{array}{c}\text { Strategic } \\
\text { Initiatives }\end{array}$} \\
\hline & Lag Indicator & $\begin{array}{l}\text { Lead } \\
\text { Indicator } \\
\end{array}$ & \\
\hline $\begin{array}{l}\text { Increase product } \\
\text { innovation }\end{array}$ & $\begin{array}{l}\text { New product } \\
\text { sales }\end{array}$ & $\begin{array}{l}\text { Innovating } \\
\text { the products }\end{array}$ & $\begin{array}{l}\text { Benchmarking } \\
\text { to other } \\
\text { manufacturing } \\
\text { company }\end{array}$ \\
\hline $\begin{array}{l}\text { Increase the } \\
\text { effectiveness of } \\
\text { MCE }\end{array}$ & $\begin{array}{l}\text { Manufacturing } \\
\text { Cycle } \\
\text { Effectiveness }\end{array}$ & $\begin{array}{l}\text { Decrease } \\
\text { non-value } \\
\text { added } \\
\text { activities }\end{array}$ & $\begin{array}{l}\text { Reduce the } \\
\text { inspection time, } \\
\text { movement time } \\
\text { and waiting/ } \\
\text { storage time }\end{array}$ \\
\hline $\begin{array}{l}\text { Improve post } \\
\text { sales service }\end{array}$ & $\begin{array}{l}\text { Yearly defect } \\
\text { product }\end{array}$ & $\begin{array}{l}\text { Improving } \\
\text { the quality } \\
\text { control }\end{array}$ & $\begin{array}{l}\text { Improve customer } \\
\text { service process }\end{array}$ \\
\hline
\end{tabular}

\section{Learning and Growth Perspectives}

\section{Employee Retention}

Formula:

Employee Retention $=\underline{\text { Total Employee Come Out }}$ Total Employee in this year

Sources: Adhyaksa (2002)

Indicator:

Indicators of Employee Retention

\begin{tabular}{|l|l|l|}
\hline Measurement & Value & Criteria \\
\hline Retention & Decreasing & Bad \\
\hline & Constant & Average \\
\hline & Fluctuated & Average \\
\hline & Increasing & Good \\
\hline
\end{tabular}

Sources: Kaplan (2000)

Result:

\begin{tabular}{|c|c|c|}
\hline \multicolumn{3}{|c|}{ Employee Retention } \\
\hline 2011 & $18.6 \%$ & \multirow{2}{*}{$\mathrm{Bad}$} \\
\hline 2012 & $9.52 \%$ & \\
\hline
\end{tabular}

\section{Employee Productivity}

Formula:

$$
\begin{array}{r}
\text { Employee Productivity }=\frac{\text { Operating Profit }}{\text { Total Emplovee }} \\
\text {. }
\end{array}
$$

Sources: Widodo (2011)

\section{Indicator:}

Indicator of Employee Productivity

\begin{tabular}{|l|l|l|}
\hline $\begin{array}{l}\text { Employee } \\
\text { productivity }\end{array}$ & Decreasing & Bad \\
\hline & Constant & Average \\
\hline & Increasing & Good \\
\hline
\end{tabular}

Sources: Kaplan (2000)

Result:

\begin{tabular}{|l|c|c|}
\hline \multicolumn{3}{|c|}{ Employee Productivity } \\
\hline 2011 & $(\operatorname{Rp} 77.598 .504)$ & \multirow{2}{*}{ Good } \\
\hline 2012 & $(\operatorname{Rp} 36.304 .297)$ & \\
\hline
\end{tabular}

\begin{tabular}{|c|c|c|c|}
\hline & mploye & $\begin{array}{l}\text { S Satisfa } \\
2 \%\end{array}$ & $\begin{array}{l}\text { atisfactory } \\
\text { ess Satisfactory }\end{array}$ \\
\hline \multirow{2}{*}{$\begin{array}{l}\text { Strategic } \\
\text { Objectives }\end{array}$} & \multicolumn{2}{|c|}{ Strategic Measurements } & \multirow{2}{*}{ Strategic Initiatives } \\
\hline & $\begin{array}{l}\text { Lag } \\
\text { Indicator }\end{array}$ & Lead Indicator & \\
\hline $\begin{array}{l}\text { Increase } \\
\text { employee skills }\end{array}$ & $\begin{array}{l}\text { Employee } \\
\text { Retention }\end{array}$ & $\begin{array}{l}\text { Development } \\
\text { of employee } \\
\text { skill }\end{array}$ & $\begin{array}{l}\text { Conduct employee } \\
\text { training program } \\
\text { routinely }\end{array}$ \\
\hline $\begin{array}{l}\text { Improve } \\
\text { productivity } \\
\text { employee }\end{array}$ & $\begin{array}{l}\text { Employee } \\
\text { productivity }\end{array}$ & $\begin{array}{l}\text { Increasing } \\
\text { of operating } \\
\text { profit }\end{array}$ & $\begin{array}{l}\text { Compensation } \\
\text { program based on } \\
\text { employee performance }\end{array}$ \\
\hline $\begin{array}{l}\text { Increase } \\
\text { employee } \\
\text { satisfaction }\end{array}$ & $\begin{array}{l}\text { Employee } \\
\text { Satisfaction }\end{array}$ & $\begin{array}{l}\text { Percentage } \\
\text { of employee } \\
\text { satisfied }\end{array}$ & $\begin{array}{l}\text { Making reward } \\
\text { program to the } \\
\text { employee who shows a } \\
\text { good performance }\end{array}$ \\
\hline
\end{tabular}

\section{Employee Satisfaction}


CONCLUSIONS, RECOMMENDATIONS, AND RESEARCH LIMITATION

\section{Conclusions}

From analysis of this research, conclusions can be drawn as following:

Current Performance Measurement System in PT. Yokatta Indonesia

Current performances measurement system in PT. Yokatta Indonesia is centralized in financial measures. In measuring the performance, PT. Yokatta Indonesia has focused on seeing the increase of sales related revenue growth and squeezing down the production cost. The company also uses profitability ratios such as Break Even Point (BEP) to measure their performance.

Implementation of Balanced Scorecard in PT. Yokatta Indonesia

Performance measurement system Balanced scorecard can be implemented in PT. Yokatta Indonesia with some considerations related with management style, additional costs, and infrastructures of the company.

\section{Recommendations}

For future research, there are some recommendations for next researchers as following:

1. The next researchers may consider conducting in different areas such as Yogyakarta and other city.

2. This research was focused in manufacturing company; hence the next researchers may consider conducting the research in trade or service sector.

3. The next researchesr may consider conducting with some different qualitative method research such as surveys and longitudinal studies in order to obtain more valid data.
4. For PT. Yokatta Indonesia, the top management should communicate the importance of using this measurement to success in running the strategy and meet the targets.

\section{Research Limitation}

Limitation of this research are:

1. The research objects in this research are focused on manufacturing company.

2. Using qualitative research in the form of case study.

3. Data is only for 2 years due to merger

\section{REFERENCES}

Adhyaksa, Y. (2002). Using Balanced Scorecard in Measuring the Performance of a Manufacturing Company (a case study in PT. Bhakti Manunggal Cipta, Batang). Unpublished Thesis, Fakutas Ekonomi, Universitas Islam Indonesia, Yogyakarta.

Flick, Uwe. (2002). Qualitative Research: theory, methods, applications in psychology and social sciences. London: SAGE Publications Ltd.

Ghozali, I. (2005). Aplikasi Analisis Multivariate dengan Program SPSS. Badan Penerbit Universitas Diponegoro.

Kaplan, R. S,. and Norton, D. P. (1996). Menerapkan Strategi Menjadi Aksi. Balanced Scorecard. Jakarta: Erlangga.

Kaplan, R. S., and Norton, D. P. (2001). Balanced Scorecard: Menerapkan Strategi Menjadi Aksi. Jakarta: Erlangga.

Kumari, N. (2011). Balanced Scorecard for Superior Organizational Performance. Manav Rachna International University. Issues in European Journal of Business and Management Vol. 3. pp. 73-86. 
Mulyadi. (1997). Akuntansi Manajemen, Konsep, Manfaat dan Rekayasa. Edisi kedua. Yogyakarta: BP STIE YKPN.

Mulyadi. (2001). Balanced Scorecard: Alat Manajemen Kontemporer Pelipatgandaan Kinerja Keuangan Perusahaan. Salemba Empat: Jakarta.

Mulyadi and Setyawan, J. (2000). Sistem Perencanaan \& Pengendalian Manajemen. Aditya Media, Yogyakarta.
Sinha, A. (2006). Balanced Scorecard: A Strategic Management Tool. Vidyasagar University. Issues in Journal of Commerce Vol. 11. pp. 71-81.

Sugiyono. (2013). Memahami Penelitian Kualitatif. Bandung: Alfabeta.

Widodo, I. (2011). Analisis Kinerja Perusahaan dengan Menggunakan Pendekatan Balanced Scorecard (Studi Kasus Pada Perusahaan Mebel PT. Jansen Indonesia). Skripsi, Fakultas Ekonomi, Universitas Dipenogoro, Semarang. 